\title{
Effect of Implementation of the Example Non-Example Method on VII Grade Students' Natural Science Psychomotor Competence in the Living System Organization Subject
}

\author{
Lufri Lufri ${ }^{1 *}$ Amrianto Amrianto ${ }^{1}$ Azwir Anhar ${ }^{2}$
}

\author{
${ }^{1}$ Dept. of Biology, Faculty of Mathematics and Science (FMIPA), Universitas Negeri Padang, Padang, Indonesia \\ ${ }^{2}$ Student of Master Degree Program of Biology Education, Math and Natural Science Faculty, Universitas Negeri \\ Padang, Padang, Indonesia \\ ${ }^{3}$ Dept. of Biology, Faculty of Mathematics and Science (FMIPA), Universitas Negeri Padang, Padang, Indonesia \\ *Corresponding author. Email: amrianto20@gmail.com
}

\begin{abstract}
Instruction in the 2013 Curriculum emphasizes more in students' activeness in looking for information and knowledge. However, based on the questionnaire spread in one school which has been implemented the 2013 Curriculum, it is known that students tend to be passive in learning, especially in asking question and giving opinion. Activities of asking questions and giving opinion is included in students' psychomotor competence. To overcome the problem above, because learning material of Organization of Living System tend to be abstract, it needs an appropriate method to make it more concrete. Therefore, example nonexample method can be implemented as an alternative solution to the problems. This method emphasizes on the use of pictures as media to make students more understand about abstract learning materials. Through pictures, students are led actively to analyze the provided pictures. The purpose of the research was to know effect of example non example method on VII grade students' natural science (IPA) psychomotor competence in Organization of Living System learning materials. It was a quasi-experimental research. It was done in grade VII of junior high school 18 Padang. Instrument used was observation sheet. Technique of data analysis used Mann Whitney U test. The Analysis was done by using SPSS software. The finding shows that there is effect of example non example method on VII grade students' natural science (IPA) psychomotor competence in organization of living system learning materials.
\end{abstract}

Keywords: example non example, competence, psychomotor

\section{INTRODUCTION}

Learning in the 2013 Curriculum emphasizes on active learning. Students are demanded to be active in searching information and finding knowledge. Active learning is very important to be implemented. Through it, students are easier to understand learning materials. It is in line with ${ }^{[1]}$, who say that students can be easier to understand learning materials through active learning. Besides that, the importance of active learning is also explained by ${ }^{[2]}$, who state that active learning should be developed. It is because the active learning is included into student-centered learning model.

Based on the demand, researcher spread questionnaire to one school which has implemented the 2013 Curriculum. The results of the questionnaire show that students are still passive in learning process. They are not brave to ask questions and express their opinions.
Activities of asking questions and giving opinion is included in students' psychomotor competence. Considering problems faced in school, the researcher proposed an alternative solution by using example non example method. Based on research done by ${ }^{[3,4]}$, the example non example method can improve students' activity in learning process.

Selection of learning method in learning process should consider the suitability of materials which would be taught ${ }^{[5]}$. The example non example method emphasizes on the use of pictures to concrete the learning materials. According to ${ }^{[6]}$, the contrast pictures is very important to support discovery learning. This method is very appropriate to be implemented to abstract learning materials to make them concrete, especially in BC (Basic Competencies) 3.6 Organization of Living Things Materials. Therefore, the researcher did a research, entitled "Effect of Example Non Example Method on VII Grade Students' Natural Science (IPA) Psychomotor 
Competence in Organization of Living Things Learning Materials".

\section{MATERIAL AND METHOD}

It was a quasi-experimental research. It was done in grade VII of junior high school 18 Padang in semester II of academic year 2018/2019. Population of research was all VII grade students in junior high school 18 Padang, who are registered in academic year 2018/2019. They are 228 students from 9 classes. Sample was taken by using purposive sampling technique by considering some criteria. The criteria are the sample classes are taught by same teacher and have similar variance scores (in order that the treatment effect can be seen clearly). Research instrument used was psychomotor observation sheet. It is completed with scoring rubrics to facilitate observers in scoring students' affective competence. It was also validated by two experts and one Natural Science (IPA) teacher. The data processing uses SPSS software. It is used to process the data in form of numbers statistically, which are homogeneity test, normality test and hypothesis testing. Technique of data analysis was done through hypothesis testing. Statistical test used was Mann-Whitney U-Test because the data are ordinal. The criteria of hypothesis testing by using Mann-Whitney U-Test are as follow.

a. $\mathrm{H}_{0}$ is accepted if sig. value $>0,05$.

b. $\mathrm{H}_{0}$ is rejected if sig. value $<0,05$.

\section{RESULT AND DISCUSSION}

\subsection{Result}

Data of students' psychomotor competence are obtained from observation done by teacher and peer as observers by using psychomotor observation sheet. The observation was done while learning process was going on. The data of students' psychomotor competence can be seen in Table 1 below.

Table 1. Average Score, Maximum Score, and Minimum score of experimental and control classes inpsychomotor competence

\begin{tabular}{cccc}
\hline Class & Average & $\begin{array}{c}\mathbf{X}_{\mathbf{m}} \\
\text { ax }\end{array}$ & \multicolumn{2}{c}{$\mathbf{X}_{\mathbf{m i}}$} \\
\hline $\begin{array}{c}\text { Experi } \\
\text { mental }\end{array}$ & 85.93 & 89 & 80 \\
\hline Control & 81.98 & 89 & 73 \\
\hline
\end{tabular}

Based on Table 1 above, it is known that the average score of psychomotor competence in experimental class (85.93) is higher than in control class (81.98), while the highest score in both classes is 89 and minimum score in experimental class is 80 and in control class is 73 .
Next, hypothesis testing was done by using MannWhitney U-Test because it is ordinal data. The result of hypothesis testing can be seen in Table 2 below.

Table 2. Result of Hypothesis Testing

\begin{tabular}{cccc}
\hline Class & ig. & $\mathbf{A}$ & Desc. \\
\hline $\begin{array}{c}\text { Experiment } \\
\text { al }\end{array}$ & 0 & 0. & $\mathrm{H}_{0}$ is \\
Control & .010 & 05 & rejected \\
\hline
\end{tabular}

Based on Table 3 above, it is known that the significant value of the hypothesis testing is 0.010 . It means that sig. value $<0.05$, so $\mathrm{H}_{0}$ is rejected. Therefore, it can be concluded that there is an effect of example non example method in scientific approach and discovery learning model on grade VII students' Natural Science (IPA) psychomotor competence in junior high school 18 Padang.

\subsection{Discussion}

From the research finding, it is known that students' psychomotor competence improves because of treatment given in experimental class. The average score in of students' psychomotor competence in experimental class is higher than in control class. In experimental class, the average score is 85.93 ; while, in control class, it is 81.98 . So, it means that the difference is 3.95 . It shows that the effect of provided treatment can improve students' psychomotor competence. Based on the result of hypothesis testing, it is known that there is a significant different between average score in experimental class and average score in control class, with sig. value is 0.010 , which means that $\mathrm{H}_{0}$ is rejected and $\mathrm{H}_{1}$ is accepted (there is a significant difference between experimental class and control class).

The example non example method is a learning method which uses picture as media in delivering learning materials. Pictures as learning media should be flexible, in which it can overcome space, time, and sense limitation ${ }^{[7]}$. Furthermore, the pictures which are chosen as learning media should be clear and able to explain or represent the learned materials ${ }^{[8]}$.

The direct observation as the result of observation, is also a form of example non example method implementation because observation result is analyzable data. The example non example method is not only limited on pictures, but also on visualized observation result. It can also be sources in example non example method implementation. The example non example method makes students more critical in analyzing pictures. Students can have chance to give opinion and understand learning materials by giving examples in from of pictures ${ }^{[9]}$.

According to ${ }^{[9]}$, through example non example method, students are involved to a) enlarge their understanding to be deeper and more complex, b) through discovery process, it encourages students to build concepts 
progressively through direct observation related to examples. Learning process can use relevant example or case related to learned basic competence ${ }^{[10]}$.

In implementing practice of BC 3.6 (Organization of Living System), students are exposed to data in forms of pictures and tables observed by them during practice process.Result of observation can support students' comprehension by making learning materials more concrete ${ }^{[11]}$. In addition, through pictures and observation result, students can be facilitated to do discovery learning activity ${ }^{[9]}{ }^{[12]}$ also explain that this method is appropriate to be collaborated with discovery model to improve students' psychomotor competence. Discovery activity is an activity that makes students active in finding knowledge so that the demand of the 2013 curriculum can be completed well. It is in line with [13] also states that through example analysis activity, students can be facilitated to prove knowledge.

\section{CONCLUSION}

The conclusion of the research is example non-example method has significant effect on students' psychomotor competence in organization of living system learning materials. In selecting learning method, it should be considered the suitability of learning materials and learning method. In addition, it should be considered students' learning styles intelligence so that learning objectives can be achieved well. For Biology teachers, it is suggested to implement example non-example method as an effort to improve students' psychomotor competence.

\section{REFERENCES}

[1] Lufri, Fitri, R., dan Yogica, R. 2018. "Development of Learning Models Based on Problem Solving and Meaningful Learning Standards by Expert Validity for Animal Development Course". In IOP Conference Series: Materials Science and Engineering, 335(1), p. 012094. IOP Publishing.

[2] Lufri, Sudirman, S., dan Rahmi, S. 2016. "Mengembangkan Skill Mengajar (Teaching Skill) Mahasiswa Calon Guru Menggunakan Multy Strategies". Ta'dib, 15(1).

[3] Setyaningsih, Y., Margereta, R., Bambang, P. 2013. "Penerapan Metode Example Non Example dalam Pembelajaran Keanekaragaman Hewan di SMPN 2 Tengaran Kabupaten Semarang". Journal of Biology Education, 2(2): 156-164.

[4] Suryani, K., Rusdi, Syafri, M. 2016. "Penerapan Metode Examples Non Examples untuk Meningkatkan Akivitas dan Hasil Belajar Matematika Siswa Kelas VII SMP Al-Karim Kota Bengkulu”. Thesis. Bengkulu: Universitas Bengkulu.

[5] Zainal, A. 2011. Micro Teaching. Jakarta: Rajawali Press.
Students' activity can encourage participation learning [14].

In learning process, students are more motivated to ask questions related to the provided pictures. Pictures can attract students' attention. Asking question is an indicator in presentation skills. In other words, improvement of students' ability in asking question also affects students' psychomotor competence. It is in line with ${ }^{[3,4]}$ also assert that example non example method is effective in improving students' activities in learning.

The optimum concentration of Andaleh root ethanol extract in inhibiting the growth of $S$. aureus and E. coli was at $12.5 \%$ and $3.125 \%$. The best concentration of ethanol extract of Andaleh stem in inhibiting the growth of $S$. aureus and E. coli was at $25 \%$. There was no antimicrobial activity of the ethanol extract of Andaleh roots and stem against the growth of $C$. albicans.

[6] Briggs, C. L. 2001. "Discovery Learning, Cognitive Psychology of". Elsevier: International Encyclopedia of the Social Science, 3736-3739.

[7] Andromeda, A., Lufri, Festiyed, Allizar, E., Iryani, I, Guspatni, G., Fitri, L. 2018. "Validity and Practicality of Experiment Integrated Guided InquiryBased Module on Topic of Colloidal Chemistry for Senior High School Learning". In IOP Conference Series: Materials Science and Engineering, 335(1), p. 012094. IOP Publishing.

[8] Oktarina, K., Lufri, dan Chatri, M. 2018. "Validity of Learning Module Natural Sciences Oriented Constructivism with the Contain of Character Education for Students of Class VIII at Junior High School". In IOP Conference Series: Materials Science and Engineering, 335(1), p. 012094. IOP Publishing.

[9] Huda, H. 2014. Model-model Pengajaran dan Pembelajaran. Yogyakarta: Pusta Pelajar.

[10] Taniredja, T., Efi, M. F., Sri, H. 2014. Modelmodel Pembelajaran Inovatif dan Efektif. Bandung: Alfabeta.

[11] Takacs, Z. K., Adriana, G. B. 2017. "How Pictures in Picture Storybooks Support Young Children's Story Comprehension: An Eye-Tracking Experiment". Elsevier: Journal of Experimental Child Psychology, 174: 1-12.

[12] Amrianto dan Lufri. 2019. "Effect of Example Non Example Method Implementation in Scientific Approach and Discovery Learning Model on VII Garde Students' Affective Competence in Learning Natural Science". International Journal of Advanced Research (IJAR), 7(3), 66-70.

[13] Knuth, E., Orit, Z., Amy., E. 2017. "The Role and Use of Examples in Learning to Prove". Elsevier: Journal of Mathematical Behavior, 1-7.

[14] Yerimadesi, Bayharti, Jannah, S. M., Lufri, Festiyed, dan Kiram, Y. 2018. "Validity and Practicality of Acid Base Module Based on Guided Discovery Learning for Senior High School". In IOP Conference Series: Materials Science and Engineering, 335(1), p. 012094. IOP Publishing. 